\title{
VARIABLE RESOURCE AVAILABILITY WHEN RESOURCE REPLENISHMENT IS CONSTANT: THE COUPLING OF PREDATORS AND PREY
}

\author{
Craig W. Benkman, ${ }^{1,3}$ Trevor Fetz, $^{2}$ and Matt V. Talluto ${ }^{1}$ \\ ${ }^{1}$ Department of Zoology and Physiology, University of Wyoming, Laramie, Wyoming 82071, USA; and \\ ${ }^{2}$ Department of Biology, New Mexico State University, Las Cruces, New Mexico 88003, USA
}

\begin{abstract}
Although food resources are thought to limit many populations, the extent to which the population dynamics of predators and prey are coupled is rarely known. We examined a sedentary population of Red Crossbills (Loxia curvirostra L. complex) that relies on seeds in cones that accumulate in the canopy of Rocky Mountain Lodgepole Pine (Pinus contorta latifolia Engelm.). Nearly constant annual seed production and gradual weathering over many years of initially impenetrable cones in the tree canopy results in a continuous and perhaps roughly constant replenishment of accessible seeds. However, seed availability varies seasonally. We estimated the seasonal variation in the energy demands of the study population. Our results demonstrate that seed predation by these sedentary Red Crossbills potentially drives the seasonal variation in seed availability and likely causes the Red Crossbill population to be regulated. The results are also consistent with a nearly constant replenishment of accessible seeds. In its apparent population stability this sedentary crossbill differs greatly from many other crossbills, which often vary in abundance by several orders of magnitude from year to year. Received 24 March 2011, accepted 23 September 2011.
\end{abstract}

Key words: bioenergetics model, crossbills, food limitation, Loxia curvirostra, Pinus contorta, population regulation, seed intake rates.

\section{Disponibilidad Variable de Recursos cuando su Reposición es Constante: El Acople entre Depredadores y Presas}

RESUMEN.-Aunque se piensa que los recursos alimenticios limitan a muchas poblaciones, el grado al que las dinámicas de las poblaciones de depredadores y presas se encuentran acopladas es poco conocido. Examinamos una población sedentaria de Loxia curvirostra que depende de semillas en conos que se acumulan en el dosel de Pinus contorta latifolia Engelm. La producción de semillas casi constante y la apertura gradual de conos inicialmente impenetrables en el dosel de los árboles a lo largo de varios años resultan en una reposición continua y casi constante de semillas accesibles. Sin embargo, la disponibilidad de las semillas varía estacionalmente. Estimamos la variación estacional en las demandas energéticas de la población de estudio. Nuestros resultados demuestran que la depredación de semillas por parte de estos individuos sedentarios de L. curvirostra potencialmente conduce a la variación estacional en la disponibilidad de semillas, lo que probablemente hace que la población de L. curvirostra sea regulada. Estos resultados también son consistentes con una reposición de semillas accesibles casi constante. En su aparente estabilidad poblacional, el L. curvirostra sedentario que estudiamos difiere de otros Loxia, los cuales a menudo fluctúan en abundancia en varios órdenes de magnitud de año a año.

FOOD SUPPLIES ARE thought to limit the size of many animal populations (Sinclair 1989, Newton 1998, Sinclair and Krebs 2002), with the depletion of food resources likely a major cause of density dependence (Begon et al. 2006). Unfortunately, the dynamics of food resources are often difficult to quantify, let alone attribute to particular consumers. For example, the foods relied upon by a given population are often consumed by several or more species and can vary in availability both seasonally and independently of consumption so that it is difficult to attribute variation in a given resource to a single consumer species. Consequently, studies of population regulation generally focus on time series analyses of population surveys or utilize experiments to alter consumer or prey abundance to detect density dependence
(Sinclair 1989, Newton 1998). Nevertheless, without measures of variation in food or other resources, we are often limited in our ability to detect density-dependent processes (Newton 1998) and to understand population dynamics (Fowler and Pease 2010). Studies that examine the dynamics of food resources and how consumers influence resource dynamics, therefore, have the potential to provide unique insights into consumer population dynamics (e.g., Grant 1986) and the coupling of predators and prey (e.g., Krebs et al. 1995).

One population for which we can characterize both resource dynamics and the effects of resource consumption is the South Hills Red Crossbill, or call type 9 (Loxia curvirostra complex; hereafter "crossbill"). These birds are sedentary in the

32E-mail: cbenkman@uwyo.edu

The Auk, Vol. 129, Number 1, pages 115-123. ISSN 0004-8038, electronic ISSN 1938-4254. @ 2012 by The American Ornithologists' Union. All rights reserved. Please direct all requests for permission to photocopy or reproduce article content through the University of California Press's Rights and Permissions website, http://www.ucpressjournals. com/reprintInfo.asp. DOI: 10.1525/auk.2011.11069 
South Hills of southern Idaho and are the main predators of, and feed almost exclusively on, seeds in the cones of Rocky Mountain Lodgepole Pine (Pinus contorta latifolia) (Smith and Benkman 2007, Benkman et al. 2009); since 1997 we have observed these crossbills actively foraging for $>50 \mathrm{~h}$ and on only a few occasions have we seen them consume anything besides Lodgepole Pine seeds, soil, and salt. Importantly, resource or seed availability for crossbills can be measured directly as seed intake rates (Benkman 1987b, 1997; Smith and Benkman 2007), with variation in seed intake rates influencing habitat use and the timing of reproduction in crossbills (Benkman 1987b, 1990). Seed intake rates (excluding scanning for predators and conspecifics) appear to be largely set by bill and cone structure and the number of seeds per cone (Benkman 1987a, b, 1993), which in combination with energy demands influence the amount of time spent foraging per day (Benkman 1990).

Smith and Benkman (2007) predicted constant seed replenishment in the South Hills because crossbills forage predominantly on seeds in older weathered cones that have accumulated in the canopy for years or even decades (Fig. 1). Most cones in the South Hills are serotinous (trees generally produce either serotinous or nonserotinous cones and $92 \%$ of the trees are serotinous; Benkman and Siepielski 2004) and remain closed until they are heated (e.g., by fire). Seeds in hard, closed serotinous cones are initially inaccessible to crossbills. As cones age and weather, however, the resinous bonds between the scales weaken so that seeds in older cones (generally $\geq 5$ years old) gradually become accessible to foraging crossbills (Fig. 1; Benkman et al. 2003). In addition, annual cone production by Lodgepole Pines is exceptionally stable in another isolated mountain range (Little Rocky Mountains, Montana) similar to the South Hills, and preliminary analyses for the South Hills indicated similar stability (Benkman et al. 2003).

Here, we evaluate the hypothesis, originally suggested by Smith and Benkman (2007), that the combined process of nearly constant replenishment of accessible Lodgepole Pine seeds and seasonally variable depletion by crossbills causes seasonal variation in seed availability, where the latter was measured as seed intake rates while actively foraging on cones. First, we present data on annual seed production in the South Hills to determine whether it was stable from year to year so that a relatively constant replenishment process is plausible. Second, we present crossbill survey data from the years of the study to evaluate whether crossbill populations were stable. Third, we estimate how energy demands of the crossbill population (i.e., daily seed depletion) varied throughout the year. Fourth, we compare seed intake rates to that predicted when seed replenishment is constant but seed depletion depends on energy demands that vary throughout the year. We find that the predicted patterns of seed intake rates closely match the observed pattern. This result indicates that seed consumption by crossbills drives seed availability and that South Hills crossbills were regulated by seed availability.

\section{Methods}

Cone and seed production.-We counted the number of cones produced in successive years along three branches in the upper third of 78 recently fallen mature Lodgepole Pines, starting with the most recent year at the branch tip (Fig. 1; Benkman et al. 2003); successive whorls of Rocky Mountain Lodgepole Pine cones are usually produced each year and retained for many years (Crossley 1956, Elliott 1988). Unlike in many conifer systems, no seed predator removes the cones from the trees; tree squirrels (Tamiasciurus and Sciurus) are absent from the South Hills and crossbills cannot remove the cones because they are so securely attached to the branches. We chose fallen trees because of the difficulty of accurately counting cones in the canopy of standing mature trees. We counted cones representing an 11-year period (1991-2001). Two closed cones that had no sign of seed predation were collected from each year from each of 69 trees with the exception of the last year (2001), when cones from only 51 trees were collected (a total of 1,482 cones). The number of full (with kernel; seeds are empty when self pollinated) seeds was counted from each of these cones so that the number of seeds produced per cone per year could be estimated for the respective trees. To determine whether the numbers of cones, seeds per cone, and total seeds per tree ( 3 branches) produced each year changed in a consistent manner over the

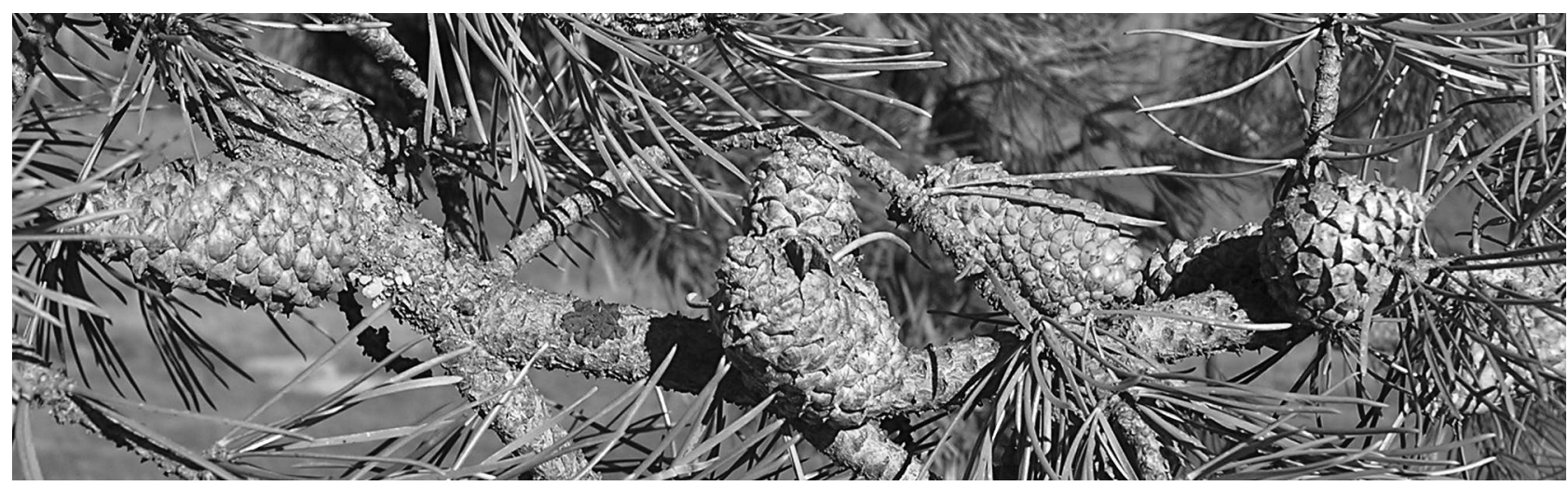

FIG. 1. Photograph of 5 years of serotinous Lodgepole Pine cones along a branch, with increasingly older cones on left. Two cones were produced during each of the first 4 years; the number of cones produced during the last year (farthest to the right) cannot be determined from the photograph. There were at least 4 additional years of more recent cones farther to the right along the branch. The cone in the middle of the photograph (from second oldest cohort) has gaps between some of the distal scales, and the bent-back scales indicate foraging by Red Crossbills. 
11 years, we used a standard least-squares regression with residual maximum-likelihood estimation and tree as a random factor.

Crossbill surveys.-To determine whether crossbill abundance varied among years, 10-min point counts were conducted following the protocol of Ralph et al. (1993). Point count locations were randomly selected using a map, compass, and random numbers table with the constraints that stands lacking extensive Lodgepole Pine were excluded and point count locations were separated by a minimum of $250 \mathrm{~m}$ to maintain independence of observations. All South Hills crossbills that were perched within $50 \mathrm{~m}$ of the point were recorded during the first and second 5-min intervals, and data are presented from both the first $5 \mathrm{~min}$ and the total $10 \mathrm{~min}$. Only data from October point counts are presented because this represented a period after breeding when both males and females should be equally detectable, and most of the young destined for early death would have died and the overall population would have largely stabilized (see Fig. 2; Julian dates for October: 274-304). Sixty-eight points were surveyed in 2000, and 74 were surveyed in 2001 and 2002.

Seasonal variation in energy demands.-We estimated the total daily energy demands of a population of crossbills, beginning with 100 adults on 1 January, using a bioenergetic model developed for birds by Wiens and Innis (1974) and revised and documented by Rexstad (1982). Here, we present a brief summary of the
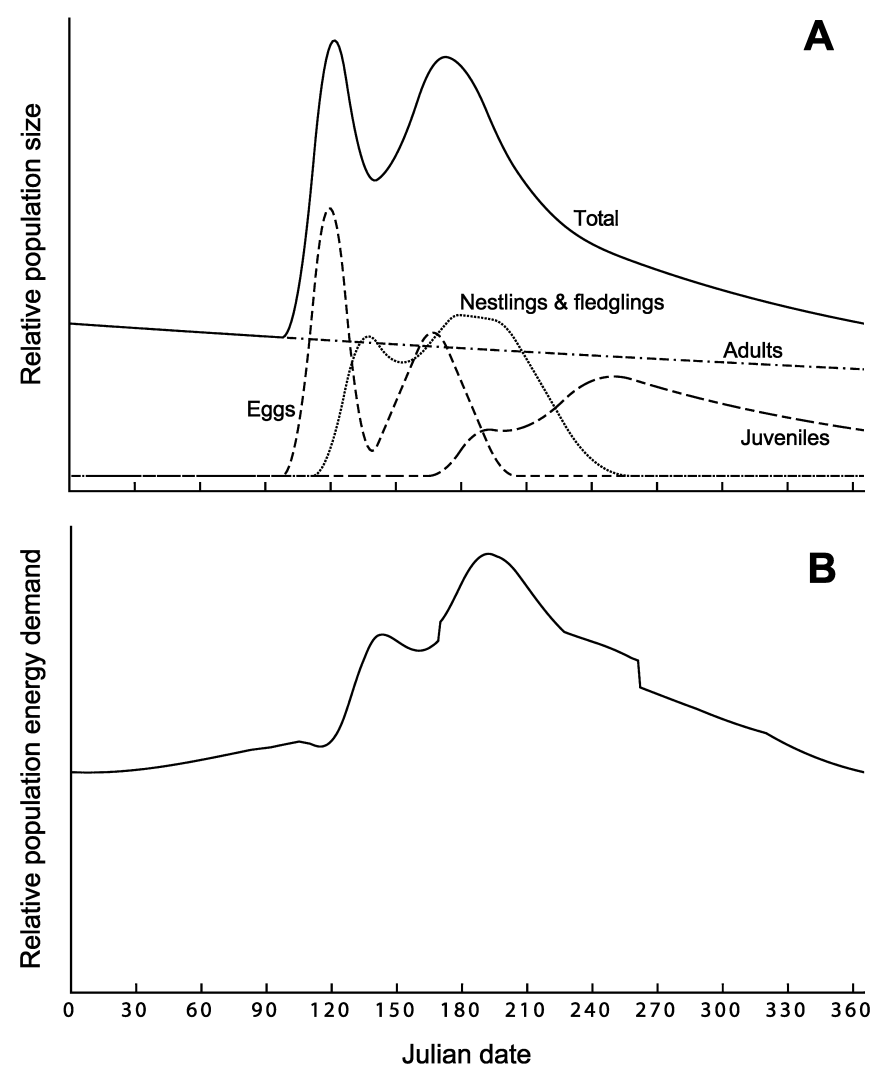

FIG. 2. Relative sizes of (A) the different components of the Red Crossbill population and $(B)$ the total energy demand by these birds throughout the year, as estimated using the model developed by Wiens and Innis (1974) and modified by Rexstad (1982). See text for values used for various parameters in the model. model structure along with details of our parameterization of the model and of changes we implemented. A complete description of the original model can be found in Wiens and Innis (1974). The model estimates daily population densities of each age class (eggs, nestlings, fledglings, juveniles, and adults) based on user input of starting adult population size, vital rates, and the timings of molting and breeding (Table 1). Following population estimation, the model uses seasonal temperature observations and estimates of mass- and life-stage-specific metabolic rates (based on seasonal costs of activity, reproduction, molting, etc.) to calculate expected daily energy demand for the population (Wiens and Innis 1974).

We used a combination of published and field-collected data to select values for all parameters (Table 1). Because we were interested in relative changes in energy demand through the year, the absolute population sizes estimated by the model (and thus the starting population size used as input) were arbitrary. For temperature data, we used mean monthly temperatures in 2001 from the Magic Mountain SNOTEL site (Natural Resources Conservation Service, U.S. Department of Agriculture) located in the study area. For some parameters, we used values from a similar simulation for crossbills (Génard and Lescourret 1987), such as egg mass when laid $(2.9 \mathrm{~g})$ and length of time from fledging until becoming a juvenile (33 days). Other parameters, such as incubation period (14 days) and time from hatching to fledging (20 days), were estimated from a more recent review of crossbills (Adkisson 1996). Where appropriate data were available, we used our studies on the South Hills crossbill (Benkman et al. 2009) to estimate model parameters (Table 1). Values related to adult and juvenile survival were based on our mark-recapture analyses indicating that adult annual survival was 0.70 and juvenile annual survival was 0.15 during our study (Santisteban et al. 2012). Parameters related to the timing of breeding and the number of breeding attempts (Table 1) were estimated based on the breeding condition of captured females and the occurrence of 50 nests located in the South Hills (Smith and Benkman 2007). We assumed that $90 \%$ of the females nested and began incubation between 8 April and 8 May, and then $90 \%$ nested during a more protracted second attempt starting 9 May and ending 11 July. These second attempts would include those nesting after a failed attempt (i.e., those nesting early in this period) and those nesting after a successful nesting attempt (i.e., those nesting later). We initially used the hatching, fledging, and postfledging success values used by Génard and Lescourret (1987; $0.76,0.62$, and 0.65 , respectively). This caused the crossbill population to increase between years. However, our survey data indicated little if any consistent change between years in the size of the crossbill population (see below), and estimates of annual adult and juvenile survival varied little over the study, further indicating a stable population (Santisteban et al. 2012). Consequently, we reduced values related to survival of eggs and nestlings, especially during the first nesting attempt (Table 1), when it snowed more often. We also reduced postfledging success and reduced the success of second broods more than that of first broods (Table 1) because of the decline in seed intake rates late in the breeding season. According to our sensitivity analyses (see Table 2), these alterations would have only a minor effect on the timing of the minimum and maximum energy demands. Moreover, assuming a stable population should not affect the timing of the minimum and maximum energy demands except in the unlikely event that the population had increased or decreased dramatically. Figure $2 \mathrm{~A}$ shows 
TABLE 1. Bioenergetic model parameters used in the Red Crossbill population model, values used, and references.

\begin{tabular}{lcl}
\hline Model parameter & Value used & Reference \\
\hline Adult daily death rate & 0.000977 & Santisteban et al. 2012 \\
Juvenile daily death rate & 0.007 & Santisteban et al. 2012 \\
Proportion of females breeding, brood 1 & 0.9 & See text \\
Proportion of females breeding, brood 2 & 0.9 & See text \\
Clutch size, brood 1 & 3 & Adkisson 1996 \\
Clutch size, brood 2 & 3 & Adkisson 1996 \\
Hatching success, brood 1 & 0.50 & See text \\
Hatching success, brood 2 & 0.70 & See text \\
Fledging success, brood 1 & 0.45 & See text \\
Fledging success, brood 2 & 0.60 & See text \\
Postfledging success, brood 1 & 0.61 & See text \\
Postfledging success, brood 2 & 0.55 & See text \\
Duration of molting (days) & 92 & P. Keenan unpubl. data \\
Duration of incubation (days) & 14 & Adkisson 1996 \\
Duration of nestling stage (days) & 20 & Adkisson 1996 \\
Duration of fledgling stage (days) & 33 & Génard and Lescourret 1987 \\
Date of onset of molting (Julian date) & 170 & P. Keenan unpubl. data \\
Date of initiation of brood 1 (Julian date) & 98 & Smith and Benkman 2007 \\
Date of completion of brood 2 (Julian date) & 128 & Smith and Benkman 2007 \\
Date of initiation of brood 2 (Julian date) & 129 & Smith and Benkman 2007 \\
Date of completion of brood 2 (Julian date) & 192 & Smith and Benkman 2007 \\
\hline
\end{tabular}

the relative sizes of the different components of the population throughout the year.

To explore the sensitivity of model predictions about the timing of minimum and maximum energy demand to changes in model parameters, we used a simulation approach similar to that outlined in Morris and Doak (2002). For the analysis, variables associated with vital rates (adult and juvenile death rate, clutch size, fledgling, nestling, and hatching success rates, and the proportion of females breeding) or durations (duration of each pre-adult life stage, duration of molting) were randomly varied within $\pm 10 \%$ of their original values, and variables associated with timings (date of molt onset, date of initiation, and completion of each brood) were varied by \pm 20 days. We ran the model with 50,000 parameter combinations and recorded the timing of the minimum and maximum seed intake rates for each replicate. Random combinations that resulted in skipped breeding attempts (because breeding was completed before initiation) were ignored, leading to 40,786 combinations. We then used the varied parameters as predictors in a series of regression models with the timing of the minimum and maximum seed intake rate as response variables. For this type of analysis, the proportion of the variance explained $\left(r^{2}\right)$ in a simple linear regression describes the sensitivity of the parameter of interest to the parameter in question (Morris and Doak 2002). To determine whether interactions between variables were of interest, we compared the proportion of variance explained by a multiple regression including only additive effects for all variables to a model also including all two-way interactions. Finally, we examined the parameter estimates of the simple linear regressions to determine the absolute effect of using the maximum and minimum for each parameter on the timing of peak seed intake rate (i.e., the number of days earlier or later in relation to the model defaults).

Predicted and observed seed intake rates.-The predicted daily seed intake rates were estimated to be linearly proportional to the size of the standing crop of available seeds; we also incorporated a nonlinear type II functional response (Holt and Kimbrell 2007), but we do not present this because it altered the results only slightly. To estimate the standing crop of available seeds, we assumed a constant production of accessible seeds that was depleted in proportion to the daily energy demands of the population. We set the production rate so that the standing crop at day 365 (31 December) was equal to the standing crop at day 1 (1 January). This allowed us to predict how seed intake rates should vary throughout the year, but not the absolute values. To aid comparison between the observed and the predicted seed intake rates, we scaled the predicted rates so that their maximum and minimum approximated those of the observed rates.

Observed seed intake rates (seeds consumed per second while a crossbill foraged on a cone) were measured by recording the number of seeds eaten during timed intervals, excluding time spent scanning for predators, between July 2000 and December 2002. Crossbills were observed with 20-60× Kowa and 40× Questar telescopes. Seed intake rates were based on a total of 1,454 timed foraging bouts for adult South Hills crossbills foraging on cones in trees from which 9,671 seeds were consumed in a total of $90,514 \mathrm{~s}$. When more than one foraging bout per individual crossbill was recorded on the same day (some crossbills were color banded, and sometimes successive foraging bouts were recorded from an individual), we used the overall mean in the analyses ( $n=1,266$ bouts; 808 for males, 454 for females, and 4 for unknown sex). Because most crossbills were not banded, we do not know how many different individuals were recorded foraging. However, we made an effort to visit numerous and widely scattered locations to avoid excessive numbers of repeated measures from the same individuals. Our foraging data for banded crossbills suggest that we were successful. Of the 27 banded crossbills from which we recorded foraging data, 19 were recorded from only 1 day, 5 were recorded on 2 days, 2 were recorded on 3 days, and 1 was recorded on 4 days. For the latter three categories, the 
TABLE 2. Results of a sensitivity analysis showing $r^{2}$ values and adjusted parameter estimates for simple linear regressions of model parameters on the timing of minimum and maximum seed intake rates for the South Hills Red Crossbill population. Parameter estimates have been adjusted to indicate the change in timing (in days) resulting from a $10 \%$ increase in the parameter (for vital rates) or a 20-day delay (for timings). Blank cells indicate a parameter that explained $<5 \%$ of the variance in minimum or maximum seed intake rates. The total proportions of the variance explained by models with all additive ("Additive model") and additive plus all 2-way interactions ("Two-way model") are shown below.

\begin{tabular}{|c|c|c|c|c|c|}
\hline \multirow{2}{*}{\multicolumn{2}{|c|}{ Model parameter }} & \multicolumn{2}{|c|}{ Timing of minimum seed intake rate } & \multicolumn{2}{|c|}{ Timing of maximum seed intake rate } \\
\hline & & $r^{2}$ & Parameter estimate & $r^{2}$ & Parameter estimate \\
\hline \multirow[t]{18}{*}{ (A) } & Vital rates and durations & & & & \\
\hline & Adult death rate & 0.052 & -5.5 & & \\
\hline & Juvenile death rate & & & & \\
\hline & Proportion of females breeding, & & & & \\
\hline & Brood 1 & & & & \\
\hline & Brood 2 & 0.109 & 8.1 & & \\
\hline & Clutch size, brood 1 & & & & \\
\hline & Clutch size, brood 2 & 0.109 & 8.1 & & \\
\hline & Hatching success, brood 1 & & & & \\
\hline & Hatching success, brood 2 & 0.106 & 7.9 & & \\
\hline & Fledging success, brood 1 & & & & \\
\hline & Fledging success, brood 2 & 0.103 & 7.8 & & \\
\hline & Postfledging success, brood 1 & & & & \\
\hline & Postfledging success, brood 2 & 0.107 & 8.0 & & \\
\hline & Duration of molt (days) & & & & \\
\hline & Duration of incubation (days) & & & & \\
\hline & Duration of nestling stage (days) & & & & \\
\hline & Duration of fledgling stage (days) & & & & \\
\hline \multirow[t]{6}{*}{ (B) } & Timings & & & & \\
\hline & Date of onset of molt & & & & \\
\hline & Date of initiation of brood 1 & & & 0.678 & 15.0 \\
\hline & Date of completion of brood 1 & & & 0.545 & 13.2 \\
\hline & Date of initiation of brood 2 & & & & \\
\hline & Date of completion of brood 2 & 0.050 & 5.5 & & \\
\hline \multirow[t]{3}{*}{ (C) } & Full models & & & & \\
\hline & Additive model & 0.879 & NA & 0.995 & NA \\
\hline & Two-way model & 0.961 & NA & 0.997 & NA \\
\hline
\end{tabular}

average interval between recordings was 48.5 days (range: 6-146 days). We used a cubic spline (R Development Core Team 2009) to describe how seed intake rates varied in relation to Julian date. We extended the Julian dates 60 days on both ends (to -60 and 416) by including data from these months twice (e.g., data from Julian date 336 were also included as Julian date -20) to better capture the shape of the relationship near Julian dates 0 and 356. This altered the shape of the cubic spline between Julian dates 310 and 356 and reduced the standard error near Julian dates 0 and 356 but did not affect the location of the maximum and minimum seed intake rates.

\section{Results}

Cone and seed production.-Annual cone production decreased slightly but significantly over the 11-year period (Fig. 3A; cones branch $^{-1}$ year $^{-1}=1.600-0.029$ year, $t=-4.65, P<0.0001$ ), whereas the number of seeds per cone and total seeds per three branches did not decline (Fig. 3B, C; $t=0.93, P=0.35$ and $t=-1.48, P=0.14$, respectively). The coefficients of variation $(\mathrm{CV})$ for among-year variation in these variables were $7.1 \%, 3.7 \%$, and $7.7 \%$, respectively, which indicates that seed production was very stable from year to year; the lowest known CV for annual seed production in any other species of plant is 22\% (Kelly and Sork 2002).

Crossbill surveys.-The number of crossbills tended to be similar from year to year $(\mathrm{CV}=12 \%$ for counts during first $5 \mathrm{~min}$ and $21 \%$ for the 10 -min counts), with the standard errors for each year overlapping with at least one other year (Fig. 4).

Seasonal variation in energy demands.-Model predictions of energy demands increased with the onset of breeding, with the first large peak in energy demands corresponding to the first nesting attempt and the second and highest peak corresponding to the second nesting attempt (Fig. 2B); these peaks lagged behind those for egg laying (Fig. 2A) because nestlings and fledglings and their care result in higher total energy costs than those for egg laying.

Predicted and observed seed intake rates.-The seasonal variation in observed seed intake rates followed that predicted on the basis of constant replenishment of accessible seeds and depletion of these seeds in proportion to the energy demands of the crossbill population (Fig. 5). The timing of the maximum seed intake rate, which occurred early in the year, was insensitive to all model parameters except those controlling the timing of the first brood. Delaying either brood initiation 

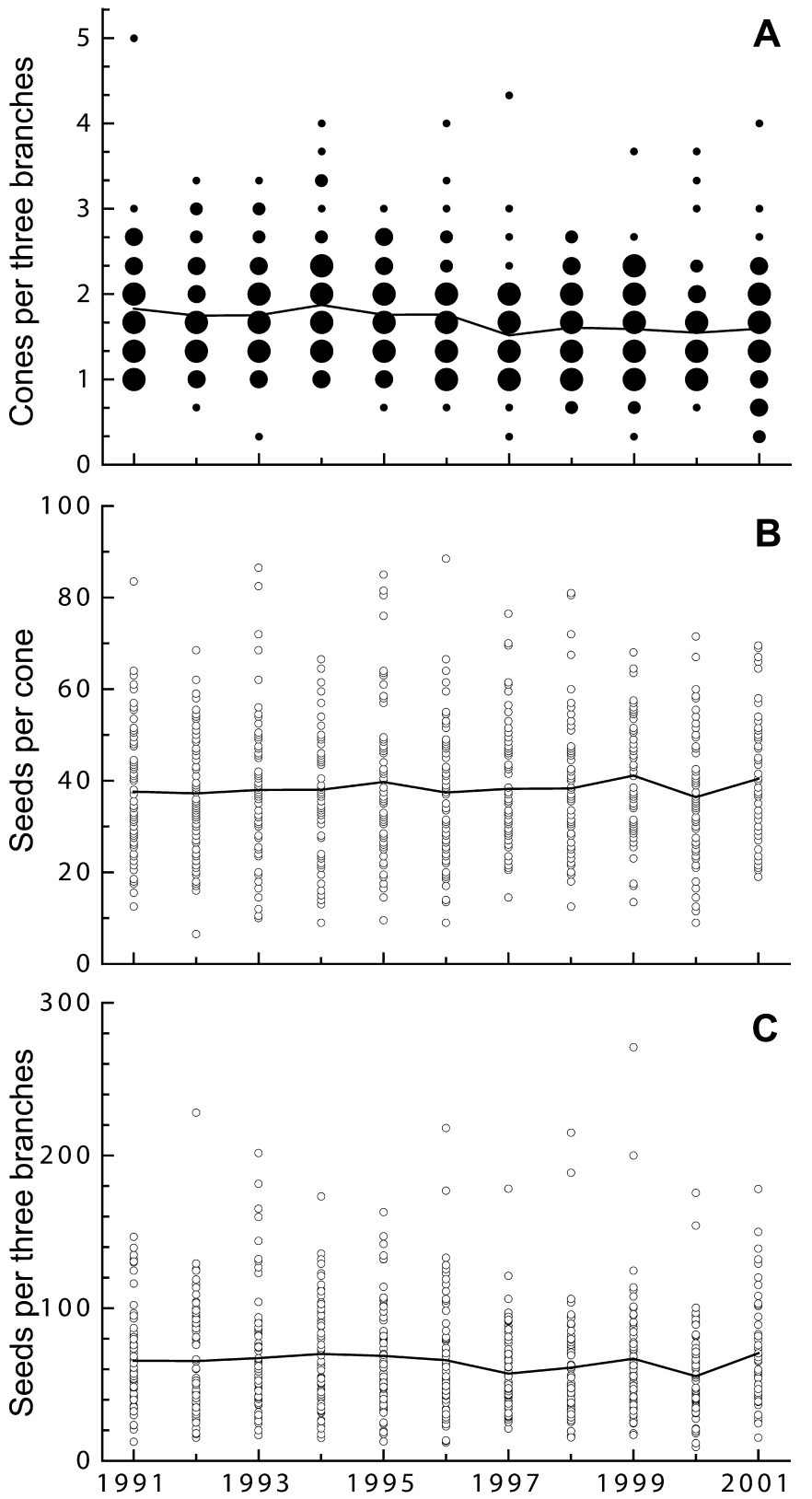

FiG. 3. Total number of (A) cones, (B) full seeds per cone, and (C) full seeds over 11 years on three upper branches from 78 mature Lodgepole Pines in the South Hills. The sizes of the symbols in A increase with increasing numbers of trees $(1-2,3-5,6-10,11-15,16-20,>20$ trees). The lines connect the yearly means.

or completion had a relatively large effect on the date at which seed intake rate peaked (Table 2). However, we are confident in our estimates for the timing of breeding, because they are based on records of 50 nests during the study (Smith and Benkman 2007) and the breeding condition (e.g., brood patches of females, fledged young) of several thousand crossbills captured in the South Hills over the past 12 years. The timing of the minimum seed intake rate was most sensitive to vital rates

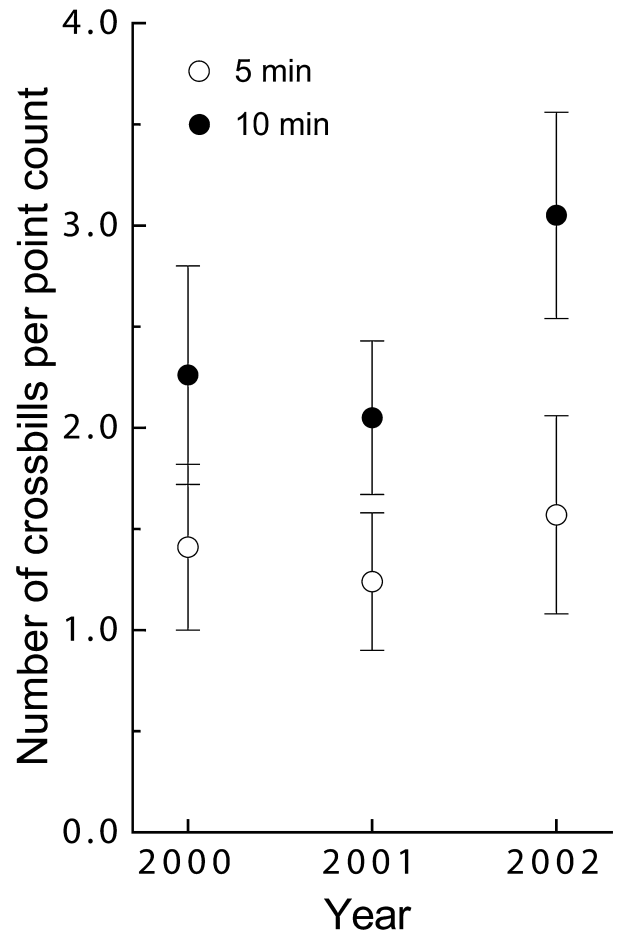

FIG. 4. Mean ( \pm SE) number of Red Crossbills observed perched within $50 \mathrm{~m}$ during 5 -and 10-min point counts during October $(n=68$ in 2000, 74 in 2001 and 2002). Data are presented for both the total count and for the first $5 \mathrm{~min}$.

associated with the second brood (Table 2), which suggests that the number of second-brood juveniles was important in determining when the minimum seed intake rate occurred. However, parameter estimates associated with the minimum seed intake rate were relatively small, with maximum delay in timing of 8.1 days associated with a $10 \%$ change in the value of the model parameter (Table 2). Such shifts are unlikely to alter our interpretation of Figure 5 much. Additive effects explained most of the variance in minimum and maximum seed intake rate $\left(r^{2}=0.879\right.$ and $r^{2}=0.995$ for minimum and maximum additive models, respectively); adding two-way interactions explained little remaining variation $\left(r^{2}=0.961\right.$ and $r^{2}=0.997$ for minimum and maximum two-way interaction models, respectively).

\section{Discussion}

The observed seasonal variation in seed intake rates of crossbills is consistent with a constant replenishment of accessible Lodgepole Pine seeds and depletion of these seeds by crossbills in relation to total population energy demands (Fig. 5). However, before we discuss the implications of this result, we address possible alternative explanations for the seasonal variation in seed intake rates. One alternative explanation is variation in motivation for feeding. For example, breeding crossbills might forage faster than nonbreeding crossbills. This, however, would not explain why seed intake rates declined during the period of greatest energy demands in summer (when adults were feeding nestlings and fledglings; Fig. 5). 


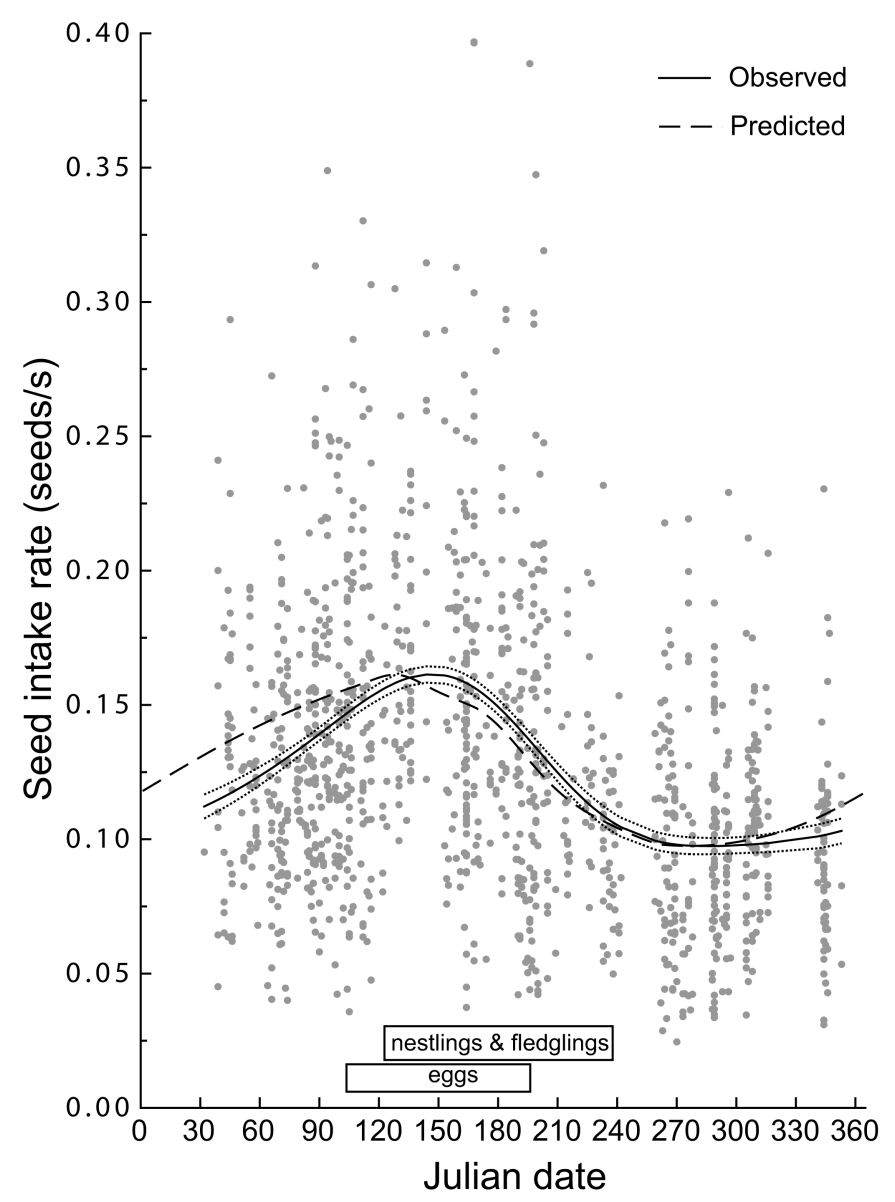

FIG. 5. Observed $( \pm$ SE) and predicted seed intake rates of South Hills crossbills throughout a year. The seasonal pattern in observed seed intake rates ( $n=1,266$ bouts) was estimated using a cubic spline. The predicted seed intake rates were based on a constant replenishment of seeds that were depleted in proportion to total energy demands (Fig. 2B).

Moreover, earlier analyses found that variation in seed intake rates was related to cone characteristics, not whether crossbills were breeding or not (Benkman 1990). Because we only included foraging data from adults, the decline in seed intake rates in summer (after May or Julian date 151) was not the result of an increase in the proportion of inefficient juveniles. In addition, the wide variation in seed intake rates and the absence of an obvious ceiling in observed seed intake rates (Fig. 5) indicate that seed accessibility rather than seed processing constraints generally limit seed intake rates (i.e., seed intake rates are a good measure of seed availability).

A second alternative is that other seed predators alter seed availability. Red Squirrels (Tamiasciurus hudsonicus), which are the most important seed predators elsewhere within most of the range of Lodgepole Pine, are absent from the South Hills. Only one species of insect (a moth, Eucosma recissoriana) feeds on seeds in Lodgepole Pine cones, but it consumes only $1 \%$ of the seeds in the South Hills (Siepielski and Benkman 2004). Moreover, moths feed on seeds only in developing cones so that they will not affect seasonal variation in seed availability to crossbills. Hairy Woodpeckers (Picoides villosus) forage on seeds in older cones, but they too consume many fewer seeds than crossbills and they have different cone preferences, so that they have relatively little effect on seed availability for crossbills (J. W. Smith and C. W. Benkman unpubl. data). Finally, two Red Crossbill call types (types 2 and 5) migrate into the South Hills mostly in May-July and most depart by August; very few remain year round, apparently because of the decline in seed availability and bill structures that make these other call types much less efficient than South Hills crossbills at foraging for seeds in the distinctive cones in the South Hills (Smith and Benkman 2007). At their peak abundance, types 2 and 5 represented $20 \%$ of the crossbills in the South Hills, but they comprised only $\sim 4 \%$ of breeding crossbills (Smith and Benkman 2007). Consequently, their demands on the seed supply were relatively minor compared to South Hills crossbills. Nevertheless, because the depletion of seeds by types 2 and 5 - which, like South Hills crossbills, feed nearly exclusively on conifer seedswould peak approximately when the seed depletion by South Hills crossbills would peak (Fig. 2B), these other crossbills would contribute to the decrease in seed availability in summer (Fig. 5).

A third alternative is that seed availability varies because of seasonal variation in cone weathering and cone opening. Seed intake rates increase as cones open and scales spread apart, making seeds more accessible to crossbills (Benkman 1987a). A prediction therefore is that cones weather and open more in winter and spring, causing seed intake rates to increase, than in summer, when seed intake rates decrease. Most of the Lodgepole Pines in the South Hills are serotinous (Benkman and Siepielski 2004), with cones opening mostly after high temperatures. For example, the exceedingly high ambient temperatures in July and August of 2003 and 2006 appear to have caused cones to open in late summer, but our observations of summer cone opening occurred subsequent to the study reported here (2000-2002). If summer cone opening had a major effect on seed availability, we would have expected seed intake rates to increase in mid- to late summer instead of decreasing (e.g., Julian dates 182-243; Fig. 5). Although the evidence does not support seasonal variation in cone weathering and opening as a driver of seasonal patterns in seed intake rates, some seasonal variation in replenishment is likely. However, such variation is apparently relatively minor compared with that caused by seed depletion by crossbills.

We are unable to think of additional plausible hypotheses. Consequently, we will address the evidence supporting the hypothesis that variation in seed intake rates results from variable depletion of seeds that become replenished at an approximately constant rate. Then we discuss the implications in terms of population regulation.

Our results support the hypothesis that seeds are produced annually at an approximately constant rate (Fig. 3C). Such small variation in annual seed production appears to be related to the absence of Red Squirrels, because in another range without Red Squirrels, the Little Rocky Mountains in north central Montana, variation is also exceedingly small ( $C V=5.1 \%$; Benkman et al. 2003). By contrast, the same subspecies of Lodgepole Pine has much greater annual variation in cone production in regions with Red Squirrels, such as in Colorado and Wyoming (CV $=61-92 \%$; Kelly and Sork 2002). This result is consistent with the hypothesis that increased variation in annual seed production acts to reduce seed predation by Red Squirrels rather than enhance wind pollination, because Lodgepole Pine is always wind pollinated (Benkman et al. 2003). Likewise, 
Janzen (1975) found similar evidence of a reduction in putative seed defenses in the absence of predispersal seed predators in another tree species. Individual Hymenaea courbaril apparently evolved from producing seed crops every few years where seed predators are present (in Costa Rica) to producing them every year where predispersal seed predators are absent (in Puerto Rico).

Similar numbers of seeds are produced annually in the South Hills (Fig. 3C), and a majority of these seeds remain in closed serotinous cones that accumulate for years in the canopy (Benkman et al. 2003, Benkman and Siepielski 2004). As cones age and weather, the resinous bonds between the scales weaken so that seeds in these older cones become increasingly accessible to foraging crossbills (Fig. 1; Benkman et al. 2003). For example, $80 \%$ of the foraging bouts in 2000-2002 were on older weathered gray cones ( $\geq 5$ years old). Stable cone production coupled with massive accumulation of cones that continually weather should result in a relatively constant replenishment of accessible seeds throughout the year. If crossbills were a continuous breeder so that energy demands remained constant, like bacteria in a chemostat, then we might expect a more constant availability of seeds. However, South Hills crossbills, like other temperate bird species, are seasonal breeders (Smith and Benkman 2007) such that the demand on the resource varies seasonally (Fig. 2B).

Because crossbills are the main predator on seeds in closed or partially closed cones in the South Hills, the demand on the resource is determined mostly by the breeding cycle and changes in crossbill density. For example, demand increased especially in May as eggs hatched and continued to remain high as young fledged and crossbills renested (Fig. 2). This demand apparently caused seed intake rates to decrease because of depletion of the most readily accessible seeds; because seed intake rates declined as demand increased, the crossbills must feed for longer to meet their demands (see Benkman 1990). Seed intake rates continued to decline until the end of September (Julian date 273; Fig. 5), when breeding was over and many of the young had died. By October, the low energy demand presumably allowed accessible seeds to accumulate as the number of seeds becoming available exceeded depletion and seed intake rates continued to increase until the next spring when crossbills nested (Fig. 5). Then demand once again exceeded replenishment, driving seed intake rates downward.

If seed consumption by crossbills and seasonal breeding drive the fluctuations in seed availability, the question remains: What determines the synchronous timing of breeding? South Hills crossbills begin nesting in the spring (nest building was first observed on 30 March 2001 and on 3 April 2002) and continue nesting into June or July depending on the year (Smith and Benkman 2007), whereas crossbills elsewhere are known to be capable of nesting nearly year round (e.g., Benkman 1990, Adkisson 1996). At least two factors likely favor spring-summer breeding even if seed availability did not vary seasonally. First, longer days and higher temperatures allow breeding at lower seed intake rates, so as seed availability is depressed by crossbills, breeding is more feasible and less energetically demanding in summer than winter. Second, crossbills undoubtedly benefit from fledging their young at the beginning of climatically favorable periods so that the young have the maximum amount of time prior to the rigors of their first winter. This may explain why crossbills begin nesting in spring rather than in summer. Once a greater proportion of the population breeds in spring and summer than during other periods, seed availability will begin fluctuating in a manner similar to what we found. This in turn will further favor spring and summer breeding.

The variation in seed intake rates indicates that seed consumption by South Hills crossbills depresses seed availability and that the extent of resource depletion is related to the energy demands of the crossbill population, which influences the number of seeds consumed. Although we do not know the extent to which crossbills are food limited at any given time, the patterns of seed availability (Fig. 5) and the similar densities of crossbills among years (Fig. 4) suggest that they are food limited. Alternatively, if crossbills were instead limited by some other factor (e.g., predators or parasites), seeds should increasingly accumulate and seed intake rates should show an overall increasing trend through the year. This is not evident in the data (Fig. 5).

Consequently, additional crossbills would likely result in further declines in seed availability, which in the spring would result in lower seed intake rates that could prevent crossbills from breeding or cause them to terminate nesting earlier in the summer (Benkman 1990) and perhaps cause greater mortality (for evidence and reviews of the importance of food availability to breeding birds and to the survival of their offspring, see Martin 1987, Arcese and Smith 1988, Newton 1998). This would act to reduce recruitment and cause the crossbill population to decline. If, on the other hand, crossbills were less abundant, so that additional accessible seeds accumulated, this would allow additional breeding and higher survival of offspring and adults and result in population growth. Such density-dependent variation in fecundity and survival would act to cause the population to be regulated. The abundance of South Hills crossbills therefore is likely limited by the replenishment of accessible seeds each year; because crossbills do not alter the replenishment rate, they are unlikely to cycle in abundance between years (i.e., exhibit supra-annual predator-prey cycling). More recently, however, South Hills crossbills have declined (Santisteban et al. 2012). This decline is thought to have occurred because of higher summer temperatures that caused many cones to open and shed their seeds, reducing the canopy seed bank and, thus, the replenishment of seeds during the rest of the year. If increasing temperatures can be linked more directly to a declining seed bank, this would further support the hypothesis that food limits crossbill abundance and provide important insight into the decline of the species.

Our results are consistent with those of many other studies that have indicated that food supplies limit bird populations (Newton 1998). Our results also suggest the coupling between the dynamics of seed availability and the life cycle of South Hills crossbills. Accessible seeds appear to be replenished at a roughly constant rate, but the sum of the annual depletion by crossbills appears to return the accessible seed supplies to consistent levels year after year. The result is that crossbills are limited by the replenishment of accessible seeds, and density-dependent depletion of these seeds acts to regulate the crossbill population. The stability of the South Hills crossbill population from year to year early in our study (Fig. 4) contrasts markedly with other Red or Common crossbill populations that can vary 25 -fold or more in local abundance between successive years (Reinikainen 1937). This range of variation in population dynamics from stability to extreme fluctuations, which largely mirrors the annual variation in the seed crops relied upon by different populations of crossbills (Reinikainen 1937, Senar et al. 1993, Watson et al. 2009), is remarkable and perhaps greater than in any other known taxa. 


\section{ACKNOWLEDGMENTS}

We thank T. Bandolin and other personnel with the U.S. Forest Service for facilitating field work, F. Lescourret and J. Wiens for sending information for estimating energy demands, and T. Hahn and an anonymous reviewer for thoughtful suggestions.

\section{Literature Cited}

AdKISson, C. S. 1996. Red Crossbill (Loxia curvirostra). In The Birds of North America, no. 256 (A. Poole and F. Gill, Eds.). Academy of Natural Sciences, Philadelphia, and American Ornithologists' Union, Washington, D.C.

ArCESE, P., AND J. N. M. SMith. 1988. Effects of population density and supplemental food on reproduction in Song Sparrows. Journal of Animal Ecology 57:119-136.

Begon, M., C. R. Townsend, And J. L. Harper. 2006. Ecology: From Individuals to Ecosystems, 4th ed. Blackwell, Malden, Massachusetts.

Benkman, C. W. 1987a. Crossbill foraging behavior, bill structure, and patterns of food profitability. Wilson Bulletin 99:351-368.

BENKMAN, C. W. 1987b. Food profitability and the foraging ecology of crossbills. Ecological Monographs 57:251-267.

BENKMAN, C. W. 1990. Foraging rates and the timing of crossbill reproduction. Auk 107:376-386.

BenKMAN, C. W. 1993. Adaptation to single resources and the evolution of crossbill (Loxia) diversity. Ecological Monographs 63:305-325

BENKMAN, C. W. 1997. Feeding behavior, flock-size dynamics, and variation in sexual selection in crossbills. Auk 114:163-178.

Benkman, C. W., T. L. Parchman, A. Favis, and A. M. SiepielSKI. 2003. Reciprocal selection causes a coevolutionary arms race between crossbills and lodgepole pine. American Naturalist 162:182-194.

BenKMAN, C. W., AND A. M. SiEPIELSKi. 2004. A keystone selective agent? Pine squirrels and the frequency of serotiny in lodgepole pine. Ecology 85:2082-2087.

Benkman, C. W., J. W. Smith, P. C. Keenan, T. L. Parchman, and L. Santisteban. 2009. A new species of Red Crossbill (Fringillidae: Loxia) from Idaho. Condor 111:169-176.

Crossley, D. I. 1956. Fruiting habits of lodgepole pine. Canadian Department of Northern Affairs and National Resources, Forest Research Division Technical Note 35.

Elliott, P. F. 1988. Foraging behavior of a central-place forager: Field tests of theoretical predictions. American Naturalist 131:159-174.

Fowler, N. L., And C. M. Pease. 2010. Temporal variation in the carrying capacity of a perennial grass population. American Naturalist 175:504-512.

GÉnard, M., And F. Lescourret. 1987. The Common Crossbill Loxia curvirostra in the Pyrenees: Some observations on its habitats and on its relations with conifer seeds. Bird Study 34:52-63.

Grant, P. R. 1986. Ecology and Evolution of Darwin's Finches. Princeton University Press, Princeton, New Jersey.

Holt, R. D., AND T. Kimbrell. 2007. Foraging and population dynamics. Pages 365-395 in Foraging: Behavior and Ecology
(D. W. Stephens, J. S. Brown, and R. C. Ydenberg, Eds.). University of Chicago Press, Chicago, Illinois.

JANZEN, D. H. 1975. Behavior of Hymenaea courbaril when its predispersal seed predator is absent. Science 189:145-147.

Kelly, D., AND V. L. SoRK. 2002. Mast seeding in perennial plants: Why, how, where? Annual Reviews of Ecology and Systematics 33:427-447.

Krebs, C. J., S. Boutin, R. Boonstra, A. R. E. Sinclair, J. N. M. Smith, M. R. T. Dale, K. Martin, and R. Turkington. 1995. Impact of food and predation on the snowshoe hare cycle. Science 269:1112-1115.

Martin, T. E. 1987. Food as a limit on breeding birds: A life-history perspective. Annual Review of Ecology and Systematics 18:453-487.

MORRIS, W. F., AND D. F. DOAK. 2002. Quantitative Conservation Biology: Theory and Practice of Population Viability Analysis. Sinauer Associates, Sunderland, Massachusetts.

Newton, I. 1998. Population Limitation in Birds. Academic Press, New York.

R Development Core Team. 2009. R: A Language and Environment for Statistical Computing. R Foundation for Statistical Computing, Vienna. [Online.] Available at www.R-project.org.

Ralph, C. J., G. R. Geupel, P. Pyle, T. E. Martin, and D. F. DESANTE. 1993. Handbook of field methods for monitoring landbirds. U.S. Department of Agriculture, Forest Service General Technical Report PSW-GTR-144.

Reinikainen, A. 1937. The irregular migrations of the crossbill, Loxia. c. curvirostra, and their relation to the cone-crop of the conifers. Ornis Fennica 14:55-64.

Rexstad, E. 1982. Bird Model, version III. Description and documentation. Utah State University, Logan.

Santisteban, L., C. W. Benkman, T. Fetz, and J. W. Smith. 2012. Survival and population size of a resident bird species are declining as temperature increases. Journal of Animal Ecology 81: in press.

Senar, J. C., A. Borras, T. Cabrera, and J. Cabrera. 1993. Testing for the relationship between coniferous crop stability and Common Crossbill residence. Journal of Field Ornithology 64:464-469.

SiePielski, A. M., AND C. W. Benkman. 2004. Interactions among moths, crossbills, squirrels and lodgepole pine in a geographic selection mosaic. Evolution 58:95-101.

Sinclair, A. R. E. 1989. Population regulation in animals. Pages 197-241 in Ecological Concepts (J. M. Cherrett, Ed.). Blackwell Scientific, Oxford, United Kingdom.

Sinclair, A. R. E., And C. J. Krebs. 2002. Complex numerical responses to top-down and bottom-up processes in vertebrate populations. Philosophical Transactions of the Royal Society of London, Series B 357:1221-1231.

Smith, J. W., and C. W. Benkman. 2007. A coevolutionary arms race causes ecological speciation in crossbills. American Naturalist 169:455-465.

Watson, A., M. MARquiss, AND R. Summers. 2009. Abundance of crossbills, siskins and cone-crops. Ornis Fennica 86:38-40.

WiENS, J. A., AND G. S. INNIS. 1974. Estimation of energy flow in bird communities: A population bioenergetics model. Ecology $55: 730-746$.

Associate Editor: K. G. Smith 